\title{
Biostimulants and cherry rootstock increased tomato fruit yield and quality in sustainable farming systems
}

\author{
Federica Caradonia, ${ }^{1}$ Domenico Ronga, ${ }^{1,2}$ Alessia Flore, ${ }^{1}$ Riccardo Barbieri, ${ }^{1}$ Lionel Moulin, ${ }^{3}$ \\ Valeria Terzi, ${ }^{4}$ Enrico Francia ${ }^{1}$ \\ ${ }^{1}$ Dipartimento di Scienze della Vita, Centro BIOGEST-SITEIA, Università degli Studi di Modena e Reggio \\ Emilia, Reggio Emilia, Italy; ${ }^{2}$ CREA - Research Centre for Animal Production and Aquaculture, Lodi, Italy; \\ ${ }^{3}$ IRD, Cirad, Univ. Montpellier, IPME, Montpellier CEDEX 5, France; ${ }^{4}$ Consiglio per la ricerca in agri- \\ coltura e l'analisi dell'economia agraria - Centro di ricerca Genomica e Bioinformatica (CREA-GB), \\ Fiorenzuola d'Arda (PC), Italy
}

\begin{abstract}
Nowadays one of the main challenges in agriculture is to increase crop yield and quality in a sustainable way. Organic farming system (OFS) is considered more eco-friendly than the conventional farming system (CFS). However, cash crops showed a reduced yield when cultivated in OFS, and among them processing tomato reported the highest yield gap between OFS and CFS. Therefore, the objective of this study was to investigate, both in greenhouse and field experiments, the combined effects of a cherry rootstock, genotype 'Tomito', and the applications of different microbial biostimulants (single species and consortia). The agronomic performance of a commercial processing tomato genotype, 'H3402', was assessed in order to increase fruit yield and quality in sustainable farming systems. In greenhouse experiment, the use of 'Tomito' as rootstock highlighted both the highest plant height (35
\end{abstract}

Correspondence: Domenico Ronga, Dipartimento di Scienze della Vita, Centro BIOGEST-SITEIA, Università degli Studi di Modena e Reggio Emilia, via Amendola 2, 42122 Reggio Emilia, Italy.

E-mail: dominic.ronga@gmail.com

Key words: Tomato; biostimulants; grafting; organic system; sustainability.

Acknowledgements: We wish to thank R. Guidetti (Furia Seed, Monticelli Terme, Italy) and M. Beretta (ISI Sementi SpA, Fidenza, Italy) for providing the seeds of the genotypes used in this work. We wish to thank Dr. Valentino Landini from Coop. Habitat (S.Vito, Ferrara, Italy) for providing the grafted plants. This research has been partially supported by BIOPRIME MiPAAF project (DIQPAIN.0003400 20/12/2018).

Received for publication: 5 October 2019

Revision received: 5 March 2020.

Accepted for publication: 28 March 2020.

${ }^{C}$ Copyright: the Author(s), 2020

Licensee PAGEPress, Italy

Italian Journal of Agronomy 2020; 15:1553

doi:10.4081/ija.2020.1553

This article is distributed under the terms of the Creative Commons Attribution Noncommercial License (by-nc 4.0) which permits any noncommercial use, distribution, and reproduction in any medium, provided the original author(s) and source are credited. $\mathrm{cm}$ ) and leaf chlorophyll content (25.20), while plants inoculated with $A$. brasiliensis showed the highest number of flowers (4.5). In field experiment, the combined use of grafting and microbial biostimulants increased marketable (on average $2.3 \mathrm{~kg} \mathrm{plant}^{-1}$ ) and total yields (on average $2.5 \mathrm{~kg} \mathrm{plant}^{-1}$ ) in comparison with the genotype 'H3402'. All the investigated treatments reduced the number of fruits affected by blossom-end rot (on average -4.7 fruits plant ${ }^{-1}$ ), and $A$. brasiliensis also improved the fruit solid soluble content, recording values of $6.23^{\circ}$ Brix and 3.54 of Brix tha ${ }^{-1}$.

\section{Introduction}

Tomato (Solanum lycopersicum L.) is one of the most cultivated horticultural crops in the world (Leogrande et al., 2012). In 2017, the world annual tomato yield exceeded 182 million tonnes over a cultivated area of $\sim 5$ million hectares (FAO, 2019). Tomato is found in many diets for its content in lycopene and other valuable anti-oxidant compounds (Raiola et al., 2014), and it is also considered a research model plant for Solanaceae (Kimura and Sinha, 2008).

Nowadays, one of the main agriculture challenges is to increase crop yield in an eco-friendly manner, combined with a reduction of synthetic products as fertilizers and plant protection products, that could increase the sustainability in crop production (Pretty, 2008; Mura et al., 2013; Ronga et al., 2019a). Nevertheless, tomato yield and quality are strictly affected by fertilizer applications (Dumas et al., 2003; Bettiol et al., 2004; Ronga et al., 2015). Farneselli et al. (2013) reported that the sustainability of farming system for processing tomato (genotypes suitable to produce canning products like tomato paste) production depends greatly on the management of soil nitrogen (N) availability. Furthermore, in OFS, where synthetic products are not allowed, yield is lower in comparison with the yield reached in CFS (Ronga et al., 2017).

Recently, the European Union has adopted a new regulation for fertilizer products, which replaces the previous one dating back to the year 2003. This regulation introduces the use of plant biostimulants, substances or microorganisms improving the plants' nutrient use efficiency, tolerance to abiotic stresses, quality traits or increasing the availability of confined nutrients in soil or rhizosphere (European Parliament and Council of the European Union, 2019). In particular, plant biostimulants based on microorganisms include different fungi as mycorrhizal fungi (e.g. Funneliformis mosseae, Rhizophagus intraradices, Glumus spp., etc.) and bacteria (such as Azotobacter spp., Rhizobium spp., and 
Azospirillum spp.) (Gouda et al., 2018; Drobek et al., 2019). Mycorrhizal fungi improve the phosphorus uptake by development of an external mycelium that overgrows the soil surrounding plant roots (Ferrol et al., 2018). Bacteria can improve growth through various mechanisms (Shameer and Prasad, 2018). In a recent study (Caradonia et al., 2019), Paraburkholderia graminis influenced nitrogen plant cycle, increasing the leaf chlorophyll content in three different processing tomato genotypes. Beside the increase of nutrients uptake, beneficial microorganisms can help plants to cope with abiotic stresses. Some studies reported that $F$. mosseae, used in the production of processing tomato seedlings, increased tolerance to chilling stress by reducing cell membrane injuries and increasing water use efficiency under drought stress (Caradonia et al., 2019; Ronga et al., 2019b). On the other hand, the bacterium Azospirillum brasilense Ab-V5 improved maize tolerance to stress by increasing nitrogen use efficiency of maize seedlings under nitrogen deficit (Zeffa et al., 2019). Recently, a study on chickpea has reported that FK1 alleviated salinity stress damage by modulating osmolytes, antioxidants machinery and stress-related genes expression (El-Esawi et al., 2019c).

The principal characteristic of plant biostimulants, especially those based on single microorganism or microbial consortia, is the ability to reduce fertilizer applications improving yield and quality of horticultural crops. Some studies reported that the combination of more sustainable strategies, such as the use of cover crops and no-tillage (da Silva et al, 2020), digestate and biochar (Ronga et al., 2020), etc., have increased the general positive effects on crop plants and have reduced the impact on environment. Therefore, we hypostasised that combining the positive effect of beneficial microorganisms with well-known agronomic techniques could improve the sustainability of the processing tomato yield per hectare when cultivated in OFS (Ronga et al., 2019c).

Among horticultural practices, grafting is an alternative to classic breeding process to exploit, in a short time, favourable traits. In addition, rootstock can affect the growth, yield and fruit quality (Flores et al., 2010; Djidonou et al., 2013).

Cherry tomato is a type of small round tomato that is studied and appreciated mainly for its fruit quality and taste (Sanchez et al., 2019). It can be considered as an intermediate genotype between wild-type and domesticated (Wang et al., 2016), with rustic characteristics and high productivity (da Silva et al., 2019). Some studies reported that tomato genotypes producing small fruits (such as cherry types) are more tolerant to abiotic stress like salinity or nutritional imbalance (Anastasio et al., 1987; Hagassou et al., 2019). Hence, the objective of this study was to investigate the agronomic effects of a cherry genotype, 'Tomito', when used as rootstock for the commercial processing genotype 'H3402' in combination with different microbial biostimulants (applied either as single species or consortia) in order to increase yield and quality of processing tomato in sustainable farming systems.

\section{Materials and methods}

\section{Plant material and treatments}

In the present work, two experiments were carried out (Table 1). In the first experiment the effects of a tomato cherry genotype and several plant growth promoting rhizobacteria (PGPR) and arbuscular mycorrhizal fungi (AMF) were evaluated under controlled condition (greenhouse). Whereas, in the second experiment, the effects of a tomato cherry genotype and several plant growth pro- moting rhizobacteria (PGPR) and arbuscular mycorrhizal fungi (AMF) were evaluated in the open field in OFS. Non-grafted and self-grafted 'H3402' plants were used as control.

Two commercial processing tomato genotypes, 'H3402' (HEINZ, Pittsburgh, Pennsylvania, USA) and 'Tomito' (ISI Sementi SpA, Fidenza, Italy), were used for these experiments. The genotype used as scion, 'H3402', has a determinate growth habit, bushy, rustic, with good vigor and yield, and medium oval fruit. This genotype is suitable for canning and it is one of the most cultivated varieties in Southern Europe (Ronga et al., 2019d). On the other hand, the genotype 'Tomito', used as rootstock, is a cherry type tomato used both for fresh market and canning; it has a determinate growth habit, is rustic and vigorous (ISI Sementi, 2020). Seeds were sown directly in plateaus $(510 \mathrm{~mm} \times 310 \mathrm{~mm} \times$ $42 \mathrm{~mm}$ ) filled with neutral commercial peat (23\% organic carbon, $0.5 \%$ organic nitrogen and dry apparent density $214 \mathrm{~kg} \mathrm{~m}^{-3}$, Dueemme S.r.l., Reggio Emilia) and germinated in greenhouse at Coop Habitat (San Vito, Ferrara, Italy) under controlled conditions (temperature: $25 / 19^{\circ} \mathrm{C}$; humidity: $\sim 60 \%$ ). The rootstock seeds were sown 4 days before the scion seeds in order to avoid an uneven development of seedlings. Grafting was performed by Coop Habitat when the seedlings had 4 trues leaves using the Japanese top grafting method also known as tube-grafting or splice grafting (Lee et al., 2010). Rootstock seedlings were cut below the cotyledons to avoid the regrowth of rootstocks. Grafting elastic tube-shaped clips with a stick were used to help the cohesion between scion and rootstock. Grafted seedlings were placed in a shaded $(50 \%)$ healing chamber for 10 days until full recovery.

After 2 weeks from grafting, seedlings were transplanted in pots $(6.5 \mathrm{~cm} \times 8 \mathrm{~cm} \times 5.5 \mathrm{~cm})$ filled with the same neutral peat. Before transplanting, arbuscular mycorrhizal fungi (AMF) $(2 \mathrm{~g}$ pot $^{-1}$ ) and the commercial product (Micosat F UNO, $10 \mathrm{~g} \mathrm{~L}^{-1}$ ) were added in pots and mixed with peat (Table 1).

Immediately after transplanting in pots, bacterial inoculum $\left(10^{7}\right.$ colony forming unit $(\mathrm{CFU}) \mathrm{mL}^{-1}$; Table 1$)$ was added close to the plant's root collar as reported by Caradonia et al. (2019). Single colonies of every bacterium were cultivated in $250 \mathrm{~mL}$ Erlenmeyer flasks containing $60 \mathrm{~mL}$ of Tryptone Soya Yeast extract broth (Caradonia et al., 2019). Flasks were incubated at $28^{\circ} \mathrm{C}$ at $150 \mathrm{rpm}$ for $24 \mathrm{~h}$. Then the suspensions were centrifuged for 4 minutes at $8000 \times \mathrm{g}$, the pelleted were washed and suspended in sterilized distilled water. Bacterial concentrations were estimated by Jasco V550 UV-VIS spectrophotometer $(600 \mathrm{~nm})$ and adjusted by sterilized distilled water.

\section{Greenhouse experiment}

After the seedlings transplant, ten seedlings per treatment were grown in greenhouse at University of Modena and Reggio Emilia with a photoperiod of $16 \mathrm{~h}$ light and $8 \mathrm{~h}$ dark and the day/night temperatures of $25 / 19^{\circ} \mathrm{C}$. Seedlings were watered every two days with $50 \mathrm{~mL}$ of water per pot. Compo BIO fluid stillage (organic nitrogen $3 \%$, potassium oxide $6 \%$ and organic carbon $10 \%$, COMPO ITALIA S.R.L, Cesano Maderno (MB), Italy) was added in the irrigation water $\left(10 \mathrm{~mL} \mathrm{~L}^{-1}\right)$ on seventh and fifteenth days.

Observed parameters were: plant height, steam diameter, height-to-steam diameter ratio, number of leaves, number of flowers, dry weight of leaves, stems and roots, total dry weight and leaf chlorophyll, flavonoid and anthocyanin contents, recorded on six seedlings per treatment on $35^{\text {th }}$ day from microbial inoculations (corresponding to flowering stage). Chlorophyll content (Chl), flavonoids (Flav) and anthocyanins (Antho) in leaves were estimated on the youngest fully expanded leaf using Dualex 4 Scientific (Dx4) (FORCE-A, Orsay, France). Nitrogen balance 
index (NBI) was calculated as the ratio between Chl and Flav as proposed by Cerovic et al. (2005). In order to determine the dry weight of different organs, leaves, stems and roots were oven-drying at $65^{\circ} \mathrm{C}$ until constant weight.

\section{Field experiment}

The effects of rootstock and biostimulant treatments on physiological and morphological parameters of the processing tomato seedlings were also assessed in OFS. The field experiment was conducted at Coop. Agricola La Collina, an organic farm located in Reggio Emilia, Northern Italy, during the growing season 2018. Weather conditions registered during the experiment are reported in the Table 2.

Seedlings were grown and inoculated in the same way of the greenhouse experiment, and on $30^{\text {th }}$ of May 2018 they were transplanted in open field (two weeks after the plant biostimulants inoculations). Plant density was 2.5 plants $\mathrm{m}^{-2}$ with a spacing of 1.60 $\mathrm{m}$ between each row and $0.25 \mathrm{~m}$ between plants in the row. Experimental design was arranged in a completely randomized design with 3 repetitions each consisting of 12 plants.

Soil had a silty loam texture $(21.3 \%$ clay, $67.5 \%$ silt, $11.2 \%$ sand), a pH 7.8 (in $\mathrm{H}_{2} \mathrm{O}$ ), 1.3\%o total $\mathrm{N}$ (Kjeldahl method), $55 \mathrm{mg}$ $\mathrm{kg}^{-1}$ available $\mathrm{P}$ (Olsen method), $179.9 \mathrm{mg} \mathrm{kg}^{-1}$ exchangeable $\mathrm{K}$ (Ammonium acetate), and $1.8 \%$ organic matter (Walkey-Black method). Field was previously fertilized with fermented cow manure (40 tha-1, N $0.5-\mathrm{P} 0.1-\mathrm{K} 0.3$ ). During the growing season, irrigation water $\left(224.4 \mathrm{~L} \mathrm{~m}^{-2}\right)$ was distributed by drip irrigation. Weeds were controlled by hand weeding while pests (such as Phytophthora infestans) were controlled by using plant protection products (such as copper compounds) allowed in OFS.

At fruit development (on 16th July 2018) and at harvest time (on $4^{\text {th }}$ September 2018), the same parameters assessed in the greenhouse experiment were recorded on four and six plants per treatments, respectively. Furthermore, number and weight of fruits were recorded in both the timing. At harvest time, when the $85 \%$ of fruits were fully ripe, plants were sampled and only the ripe fruits were considered for the marketable yield. Furthermore, leaf area index (LAI) was measured using fresh leaves that were run

Table 1. Information on genotypes, microorganisms and dose used in the experiments.

\begin{tabular}{|c|c|c|c|c|}
\hline Treatments & Genotype & Microorganisms & Dose & Information \\
\hline $\mathrm{T} 1$ & H3402xTomito & Funneliformis mosseae & $\begin{array}{l}2 \mathrm{~g} \text { seedling }{ }^{-1} \\
(1 \mathrm{~g} \text { of inoculum contained } 10 \text { propagules })\end{array}$ & $\begin{array}{l}\text { Provided by } \\
\text { MycAgro, LabTechnopôle Agro } \\
\text { Environnement, Bretenière, France }\end{array}$ \\
\hline $\mathrm{T} 2$ & H3402xTomito & $\begin{array}{l}\text { MICOSAT F UNO } \\
40 \% \text { Funghi simbionti } \\
\text { (Glomus spp. GB } 67, \\
\text { Funneliformis mosseae } \\
\text { GP } 11, \text { G. viscosum } \mathrm{GC} 41 \text { ) } \\
18,60 \% \text { C.F.U. } \mathrm{g}^{-1} \text { : } 12,4 \text { x } 10^{7} \\
\text { Batteri della rizosfera } \\
\text { (Agrobacterium radiobacter } \\
\text { AR } 39, \text { Bacillus subtilis } \text { BA } 41 \text { e } \\
\text { Streptomyces spp. SB } 14 \text { ) } \\
\text { Funghi saprofiti (Pochonia } \\
\text { chlamydosporia PC } 50 \text { e } \\
\text { Trichoderma harzianum TH 01) } \\
\text { Lieviti (Pichia pastoris } \text { PP 59) }\end{array}$ & $10 \mathrm{~g} \mathrm{~L}^{-1}$ & Produced by CCS (Aosta, Italy) \\
\hline T3 & H3402xTomito & Paraburkholderia graminis C4D1M & $\begin{array}{l}1 \mathrm{~mL} \text { seedling } \\
\left(10^{7} \mathrm{CFU} \mathrm{mL}^{-1}\right)\end{array}$ & CREA GB 's Collection \\
\hline T4 & H3402xTomito & Azospirillum brasiliensis sp. 245 & $\begin{array}{l}1 \mathrm{~mL}^{2} \text { seedling } \\
\left(10^{7} \mathrm{CFU} \mathrm{mL}^{-1}\right)\end{array}$ & CREA GB 's Collection \\
\hline $\mathrm{T} 5$ & H3402xTomito & $\begin{array}{l}\text { Funneliformis mosseae } \\
+ \text { all bacteria }\end{array}$ & $\begin{array}{l}2 \mathrm{~g} \text { of } F \text {. mosseae }+1 \mathrm{~mL} \\
\text { of each bacterium inoculum per seedling }\end{array}$ & \\
\hline $\mathrm{T} 6$ & H3402xTomito & all bacteria & $1 \mathrm{~mL}$ of each bacterium inoculum per seedling & \\
\hline $\mathrm{T} 7$ & $\mathrm{H} 3402$ & non-inoculated & & \\
\hline T8 & H3402xH3402 & non-inoculated & & \\
\hline$\underline{\mathrm{T} 9}$ & H3402xTomito & non-inoculated & & \\
\hline
\end{tabular}

Table 2. Weather conditions recorded during the growing season.

\begin{tabular}{lcccc} 
Month & Total Rainfall $(\mathrm{mm})$ & Average Min Temp. $\left({ }^{\circ} \mathrm{C}\right)$ & Average Max Temp. $\left({ }^{\circ} \mathrm{C}\right)$ & Average Relative Humidity $(\%)$ \\
May & 105.8 & 15.2 & 24.0 & 63.1 \\
June & 110.6 & 18.3 & 28.7 & 52.7 \\
\hline July & 42.4 & 21.0 & 31.8 & 53.1 \\
August & 12.8 & 21.6 & 32.2 & 48.7 \\
\hline September & 7.6 & 17.5 & 27.4 & 56.7 \\
\hline
\end{tabular}


through the leaf area meter LI-3000A and linked to number of plants in a square meter. For fruit quality, the following parameters were evaluated: average fruit weight, number of fruits, number of fruits affected by blossom-end rot (BER), $\mathrm{pH}$ and Brix degree ( ${ }^{\circ}$ Brix). Total soluble solid content $\left({ }^{\circ}\right.$ Brix) was determined using the digital refractometer HI 96814 (Hanna, Italy), while the $\mathrm{pH}$ was measured by $\mathrm{pH}$ meter $\mathrm{pH} 8+$ DHS (XS INSTRUMENTS, Italy). Brix t ha-1 was calculated by multiplying the hectare marketable yield by the solid soluble content ( ${ }^{\circ}$ Brix) and dividing the result by 100 .

\section{Statistical analysis}

All the investigated parameters were analysed by ONE-way ANOVA using GenStat 17th (VSN International, Hemel Hempstead, UK). Means were compared using Bonferroni's test. Principal Component Analysis (PCA) was performed by using PLS Toolbox software (Eigenvector Research Inc, Wenatchee, WA, USA), in order to evaluate the relationships among treatments and parameters assessed in the present study.

\section{Results}

\section{Greenhouse experiment}

The use of the rootstock 'Tomito' increased the leaf chlorophyll content (Table 3). Highest $\mathrm{Chl}$ values were achieved by grafted plants ('H3402 x 'Tomito') inoculated with the microbial consortium ( $F$. mosseae + all the bacteria). The grafting technique influenced leaf flavonoid (Flv) content, increasing the Flv values of self-grafted $v s$ non-grafted plants. Nevertheless, the highest Flv values were achieved by grafted plants inoculated with the commercial product Micosat F UNO or with the microbial consortium. A negative effect of grafting technique was recorded on plant height (Table 4). Even so, the use of 'Tomito' as rootstock increased the plant height and the grafted plants inoculated with $P$. graminis C4D1M achieved the highest values of plant height. On the other hand, grafting technique increased the number of leaves and flowers in comparison with the non-grafted plants. Among

Table 3. Treatment effects on physiological parameters in greenhouse experiment.

\begin{tabular}{|c|c|c|c|c|}
\hline Treatments & Chl & Flv & Antho & NBI \\
\hline $\mathrm{FM}$ & $27.11 \pm 1.9^{a b}$ & $1.09 \pm 0.1^{a b}$ & $0.24 \pm 0.02 \mathrm{~ns}$ & $25.31 \pm 3.7 \mathrm{~ns}$ \\
\hline MICOSAT F & $25.59 \pm 1.3^{\mathrm{ab}}$ & $1.17 \pm 0.1^{\mathrm{a}}$ & $0.25 \pm 0.02 \mathrm{~ns}$ & $22.27 \pm 3.0 \mathrm{~ns}$ \\
\hline $\mathrm{PG}$ & $27.11 \pm 1.9^{a b}$ & $1.07 \pm 0.1^{\mathrm{ab}}$ & $0.26 \pm 0.01 \mathrm{~ns}$ & $25.33 \pm 1.9 \mathrm{~ns}$ \\
\hline $\mathrm{AB}$ & $25.66 \pm 3.2^{\mathrm{ab}}$ & $1.04 \pm 0.1^{\mathrm{ab}}$ & $0.28 \pm 0.01 \mathrm{~ns}$ & $24.95 \pm 4.0 \mathrm{~ns}$ \\
\hline CM FM & $29.43 \pm 2.8^{a}$ & $1.11 \pm 0.1^{\mathrm{a}}$ & $0.28 \pm 0.03 \mathrm{~ns}$ & $26.69 \pm 4.1 \mathrm{~ns}$ \\
\hline $\mathrm{CM}$ & $25.88 \pm 1.4^{a b}$ & $1.07 \pm 0.1^{\mathrm{ab}}$ & $0.27 \pm 0.03 \mathrm{~ns}$ & $24.52 \pm 3.5 \mathrm{~ns}$ \\
\hline H3402 & $23.93 \pm 1.9^{b}$ & $0.89 \pm 0.1^{b}$ & $0.24 \pm 0.04 \mathrm{~ns}$ & $26.88 \pm 1.8 \mathrm{~ns}$ \\
\hline H3402 x H3402 & $23.35 \pm 3.0^{\mathrm{b}}$ & $1.08 \pm 0.1^{\mathrm{ab}}$ & $0.29 \pm 0.04 \mathrm{~ns}$ & $21.72 \pm 2.7 \mathrm{~ns}$ \\
\hline H3402 x Tomito & $25.20 \pm 2.1^{\mathrm{ab}}$ & $1.05 \pm 0.1^{\mathrm{ab}}$ & $0.26 \pm 0.04 \mathrm{~ns}$ & $24.09 \pm 2.8 \mathrm{~ns}$ \\
\hline P values & 0.002 & 0.015 & 0.111 & 0.093 \\
\hline F values & 3.830 & 2.740 & 1.760 & 1.84 \\
\hline
\end{tabular}

Table 4. Treatment effects on morphological no- destructive parameters in greenhouse experiment.

\begin{tabular}{|c|c|c|c|c|c|}
\hline Treatments & Plant height $(\mathrm{cm})$ & Stem diameter (mm) & $\mathrm{HD}^{-1}(\mathrm{~mm})$ & Number of leaves & Number of flowers \\
\hline FM & $35.25 \pm 2.3 \mathrm{bcd}$ & $4.87 \pm 0.3 \mathrm{~ns}$ & $72.45 \pm 5.7 \mathrm{abc}$ & $9.50 \pm 1.2^{\mathrm{a}}$ & $1 \pm 0.63^{\mathrm{cd}}$ \\
\hline MICOSAT F & $39.17 \pm 2.1^{\text {ab }}$ & $4.82 \pm 0.2 \mathrm{~ns}$ & $81.40 \pm 6.7^{\mathrm{ab}}$ & $9.66 \pm 0.2^{\mathrm{a}}$ & $2 \pm 0.89^{\mathrm{bc}}$ \\
\hline $\mathrm{PG}$ & $39.83 \pm 3.1^{\mathrm{a}}$ & $4.66 \pm 0.5 \mathrm{~ns}$ & $86.51 \pm 12.7^{\mathrm{a}}$ & $9.33 \pm 0.8^{\mathrm{a}}$ & $1 \pm 0.63^{\mathrm{cd}}$ \\
\hline $\mathrm{AB}$ & $35.33 \pm 1.8^{\mathrm{abcd}}$ & $4.90 \pm 0.3 \mathrm{~ns}$ & $71.84 \pm 6.2^{\mathrm{abc}}$ & $8.50 \pm 1.4^{\mathrm{ab}}$ & $4.5 \pm 0.54^{\mathrm{a}}$ \\
\hline CM FM & $32.33 \pm 1.8^{\mathrm{de}}$ & $4.70 \pm 0.3 \mathrm{~ns}$ & $68.92 \pm 4.5^{\mathrm{bc}}$ & $9.00 \pm 0.6^{\mathrm{ab}}$ & $1 \pm 0.63^{\mathrm{cd}}$ \\
\hline $\mathrm{CM}$ & $37.33 \pm 2.1^{\mathrm{abc}}$ & $5.06 \pm 0.3 \mathrm{~ns}$ & $73.89 \pm 4.5^{\mathrm{abc}}$ & $9.83 \pm 0.7^{\mathrm{a}}$ & $3 \pm 0.63^{b}$ \\
\hline $\mathrm{H} 3402$ & $34.00 \pm 2.5^{\text {cde }}$ & $4.88 \pm 0.4 \mathrm{~ns}$ & $70.06 \pm 8.5^{\mathrm{bc}}$ & $7.50 \pm 1.0^{b}$ & $0 \pm 0^{\mathrm{d}}$ \\
\hline H3402 x H3402 & $30.17 \pm 1.2^{\mathrm{e}}$ & $4.60 \pm 0.2 \mathrm{~ns}$ & $65.57 \pm 3.0^{c}$ & $8.66 \pm 0.5^{\mathrm{ab}}$ & $1 \pm 0.63^{\mathrm{cd}}$ \\
\hline H3402 x Tomito & $35.00 \pm 3.3^{\mathrm{bcd}}$ & $4.45 \pm 0.3 \mathrm{~ns}$ & $79.07 \pm 11.3^{\mathrm{abc}}$ & $9.17 \pm 0.7^{\mathrm{ab}}$ & $1.5 \pm 0.54^{c}$ \\
\hline F values & $<0.001$ & 0.07 & $<0.001$ & 0.002 & $<0.001$ \\
\hline F values & 10.740 & 1.99 & 4.520 & 3.860 & 32.620 \\
\hline
\end{tabular}

The data are reported as mean \pm standard deviation. a,b,c,de Means followed by the different letters are statistically significant at $\mathrm{P}<0.05$; ns, not significant, Ch, index of chlorophyll content in the leaves; Flv, index of flavonoid content in the leaves; Antho, index of anthocyanin content in the leaves; NBI, nitrogen balance index. FM, 'H3402' grafted onto 'Tomito' and inoculated with Funneliformis mosseae, PG,'H3402' grafted onto 'Tomito' and inoculated with Paraburkholderia graminis C4D1M, AB,'H3402' grafted onto 'Tomito' and inoculated with Azospirillum brasiliensis sp 245, CM FM, 'H3402' grafted onto 'Tomito' and inoculated with F. mosseae, P. graminis C4D1M and A. brasiliensis sp 245, CM, 'H3402' grafted onto 'Tomito' and inoculated with P. graminis C4D1M and A. brasiliensis sp 245, 'H3402' = 'H3402' non-grafted and non-inoculated, H3402 $\mathrm{x}$ H3402 = 'H3402' self-grafted and non-inoculated, H3402 x Tomito = 'H3402' grafted onto 'Tomito' and non-inoculated. 
microbial treatments, $F$. mosseae, Micosat F UNO, $P$. graminis and the bacterial consortium achieved the highest number of leaves, while $A$. brasiliensis sp. 245 induced early flowering. Although, an increase of dry weights was recorded in all grafted plants (Table 5 ), the plants inoculated with bacterial consortium displayed the highest values for leaf dry weight, steam dry weight and plant dry weight. On the other hand, plants inoculated with Micosat F UNO recorded the highest values for root dry weight. The contri- butions of the two principal components were $43.17 \%$ (PC1) and $18.86 \%$ (PC2) (Figure 1). PC2 separated the plants grafted onto 'Tomito' from non-grafted and self-grafted plants. P. graminis and Micosat F UNO were associated with high values of root dry weight, plant height and ratio between plant height and stem diameter, while $A$. brasiliensis sp. 245 and the bacterial consortium were associated with high values of number of flowers and leaf chlorophyll content.

Table 5. Treatment effects on morphological no- destructive parameters in greenhouse experiment.

\begin{tabular}{|c|c|c|c|c|}
\hline Treatments & Leaf dry weight (g) & Steam dry weight (g) & Root dry weight (g) & Plant total dry weight (g) \\
\hline FM & $1.53 \pm 0.11^{\mathrm{ab}}$ & $1.23 \pm 0.08^{\mathrm{ab}}$ & $0.59 \pm 0.16^{\mathrm{ab}}$ & $3.41 \pm 0.32^{\mathrm{ab}}$ \\
\hline MICOSAT F & $1.50 \pm 0.26^{\mathrm{ab}}$ & $1.19 \pm 0.27^{\mathrm{ab}}$ & $0.76 \pm 0.17^{\mathrm{a}}$ & $3.68 \pm 0.38^{a b}$ \\
\hline $\mathrm{PG}$ & $1.55 \pm 0.21^{a b}$ & $1.20 \pm 0.14^{a b}$ & $0.57 \pm 0.08^{a b}$ & $3.50 \pm 0.34^{a b}$ \\
\hline $\mathrm{AB}$ & $1.45 \pm 0.24^{a b}$ & $1.26 \pm 0.13^{a b}$ & $0.58 \pm 0.14^{a b}$ & $3.52 \pm 0.44^{a b}$ \\
\hline CM FM & $1.58 \pm 0.11^{a b}$ & $1.30 \pm 0.17^{a}$ & $0.53 \pm 0.09 \mathrm{ab}$ & $3.52 \pm 0.32^{\mathrm{ab}}$ \\
\hline $\mathrm{CM}$ & $1.71 \pm 0.14^{\mathrm{a}}$ & $1.38 \pm 0.08^{a}$ & $0.59 \pm 0.05^{\mathrm{ab}}$ & $3.85 \pm 0.18^{a}$ \\
\hline H3402 & $1.22 \pm 0.20^{b}$ & $1.02 \pm 0.09^{b}$ & $0.52 \pm 0.05^{b}$ & $2.75 \pm 0.20^{c}$ \\
\hline H3402 x H3402 & $1.40 \pm 0.09^{a b}$ & $1.18 \pm 0.06^{\mathrm{ab}}$ & $0.54 \pm 0.13^{\mathrm{ab}}$ & $3.12 \pm 0.18^{b c}$ \\
\hline H3402 x Tomito & $1.35 \pm 0.08^{a b}$ & $1.13 \pm 0.09^{a b}$ & $0.55 \pm 0.11^{\mathrm{ab}}$ & $3.27 \pm 0.31^{\mathrm{abc}}$ \\
\hline P values & 0.004 & 0.006 & 0.049 & $<0.001$ \\
\hline F values & 3.390 & 3.160 & 2.58 & 6.390 \\
\hline
\end{tabular}

The data are reported as mean \pm standard deviation. a,b,cmeans followed by the different letters are statistically significant at $\mathrm{P}<0.05$; ns, not significant, Ch, index of chlorophyll content in the leaves; Flv, index of flavonoid content in the leaves; Antho, index of anthocyanin content in the leaves; NBI, nitrogen balance index. FM, 'H3402' grafted onto 'Tomito' and inoculated with Funneliformis mosseae, PG,'H3402' grafted onto 'Tomito' and inoculated with Paraburkholderia graminis C4D1M, AB,'H3402' grafted onto 'Tomito' and inoculated with Azospirillum brasiliensis sp 245, CM FM, 'H3402' grafted onto 'Tomito' and inoculated with F. mosseae, P. graminis C4D1M and A. brasiliensis sp 245, CM, 'H3402' grafted onto 'Tomito' and inoculated with P. graminis C4D1M and A. brasiliensis sp 245 , 'H3402' = 'H3402' non-grafted and non-inoculated, H3402 x H3402 = 'H3402' self-grafted and non-inoculated, H3402 x Tomito = 'H3402' grafted onto 'Tomito' and non-inoculated.

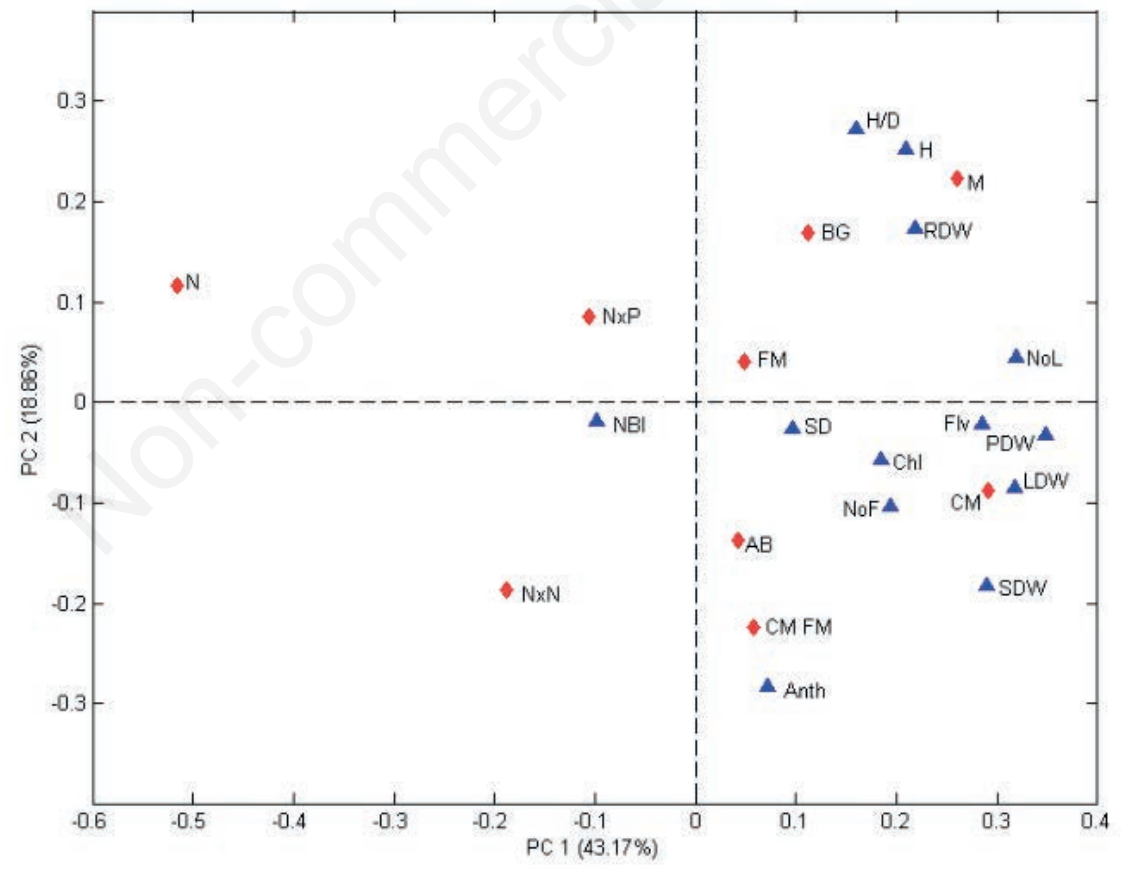

Figure 1. Biplot of PCA for the greenhouse experiment. $\mathrm{Chl}=$ index of chlorophyll content in the leaves; Flv = index of flavonoid content in the leaves; Anth = index of anthocyanin content in the leaves; NBI = nitrogen balance index, $\mathrm{H}=$ plant height, $\mathrm{SD}=$ stem diameter, $\mathrm{NoL}=$ number of leaves, $\mathrm{NoF}=$ number of flowers, $\mathrm{H} / \mathrm{D}=$ ratio between plant height and stem diameter, $\mathrm{LDW}=\mathrm{Leaf}$ dry weight, SDW = stem dry weight, $\mathrm{RDW}=$ root dry weight, $\mathrm{PDW}=$ plant dry weight, $\mathrm{M}=\mathrm{H} 3402$ ' grafted onto 'Tomito' and inoculated with MICOSAT F UNO, FM = 'H3402' grafted onto 'Tomito' and inoculated with Funneliformis mosseae, PG = 'H3402' grafted onto 'Tomito' and inoculated with Paraburkholderia graminis C4D1M, AB = 'H3402' grafted onto 'Tomito' and inoculated with Azospirillum brasiliensis sp 245, CM FM = 'H3402' grafted onto 'Tomito' and inoculated with F. mosseae, P. graminis C4D1M and A. brasiliensis sp $245, \mathrm{CM}=$ ' $\mathrm{H} 3402$ ' grafted onto 'Tomito' and inoculated with $P$. graminis $\mathrm{C} 4 \mathrm{D} 1 \mathrm{M}$ and $A$. brasiliensis sp $245, \mathrm{~N}=$ 'H3402' non-grafted and non-inoculated, $\mathrm{NxN}=$ 'H3402' self-grafted and non-inoculated, $\mathrm{NxP}=$ ' $\mathrm{H} 3402$ ' grafted onto 'Tomito' and non-inoculated. 


\section{Field experiment}

Unfortunately, during the growing season 2018 heavy rains and high moisture conditions allowed the spread of the oomicete Phytophthora infestans that was only partially controlled by foliar spray application using copper treatments in the field. The spread of pathogen was homogeneous among treatments.

\section{Measurements at fruit development}

The applied treatments (rootstock, grafting technique and plant biostimulants) did not significantly affected the physiological parameters (Chl, Flv and Antho content and NBI; Table S1). On the other hand, the grafting technique reduced the number of leaves, while the use of rootstock 'Tomito' increased this morphological parameter in comparison with non-grafted and non-inoculated plants (Table 6). For the number of fruits, the use of rootstock 'Tomito' increased this parameter, and the highest values were achieved by combining grafting with inoculation of Micosat $\mathrm{F}$ UNO or P. graminis C4D1M (Table 7).

The use of rootstock 'Tomito' influenced leaf and stem dry weight parameters (Table 7). The highest values were recorded by grafted plants inoculated with $F$. mosseae + all the bacteria. In addition, grafted plants inoculated with $P$. graminis C4D1M showed the highest root dry weight values. Fruit dry weight increased in response to grafting. Nonetheless, the highest values were achieved by grafted plants inoculated with $P$. graminis C4D1M. Finally, grafted plants inoculated with $F$. mosseae + all bacteria showed the highest values of plant dry weights.

\section{Measurements at harvest time}

Although all the treatments increased the marketable yield, the major effect was displayed by microbial inoculations (Figure 2). In fact, grafted plants inoculated with Micosat F UNO, P. graminis C4D1M and the bacterial consortium showed the highest marketable yield, the grafted plants inoculated with bacterial consortium showed also the highest leaf area index (LAI) (Table 8). Considering the physiological parameters, grafting increased the leaf chlorophyll content. On the other hand, the main effects on leaf flavonoid content was highlighted by microbial biostimulant treatments: grafted plants inoculated with P. graminis C4D1M showed a reduction in comparison with non-grafted non-inoculated ones; whereas, the same plants inoculated with A. brasiliensis

Table 6. Treatment effects on morphological no- destructive parameters in field experiment at fruit development.

\begin{tabular}{|c|c|c|c|c|}
\hline Treatments & Number of leaves & Number of fruits & Plant Height (cm) & Stem Diameter (cm) \\
\hline FM & $69.75 \pm 7.09^{\mathrm{ab}}$ & $55.50 \pm 10.87^{\mathrm{ab}}$ & $89.75 \pm 9.17 \mathrm{~ns}$ & $1.62 \pm 0.17 \mathrm{~ns}$ \\
\hline MICOSAT F & $74.50 \pm 16.98^{\mathrm{ab}}$ & $70.00 \pm 6.48^{\mathrm{a}}$ & $86.75 \pm 7.22 \mathrm{~ns}$ & $1.82 \pm 0.25 \mathrm{~ns}$ \\
\hline $\mathrm{PG}$ & $86.00 \pm 6.78^{a}$ & $71.50 \pm 8.38^{a}$ & $91.75 \pm 11.78 \mathrm{~ns}$ & $1.80 \pm 0.21 \mathrm{~ns}$ \\
\hline $\mathrm{AB}$ & $73.25 \pm 15.06^{\mathrm{ab}}$ & $46.00 \pm 10.80^{\mathrm{ab}}$ & $76.75 \pm 2.98 \mathrm{~ns}$ & $1.83 \pm 0.26 \mathrm{~ns}$ \\
\hline CM FM & $91.00 \pm 10.06^{\mathrm{a}}$ & $61.00 \pm 10.72^{\mathrm{ab}}$ & $89.25 \pm 13.76 \mathrm{~ns}$ & $1.80 \pm 0.14 \mathrm{~ns}$ \\
\hline $\mathrm{CM}$ & $82.50 \pm 2.88^{\mathrm{a}}$ & $49.75 \pm 5.56^{\mathrm{ab}}$ & $98.75 \pm 5.61 \mathrm{~ns}$ & $1.55 \pm 0.13 \mathrm{~ns}$ \\
\hline $\mathrm{H} 3402$ & $69.75 \pm 7.54^{\mathrm{ab}}$ & $37.00 \pm 4.54^{b}$ & $86.00 \pm 6.16 \mathrm{~ns}$ & $1.75 \pm 0.13 \mathrm{~ns}$ \\
\hline H3402 x H3402 & $57.25 \pm 4.85^{b}$ & $37.50 \pm 17.84^{\mathrm{b}}$ & $86.75 \pm 12.58 \mathrm{~ns}$ & $1.67 \pm 0.15 \mathrm{~ns}$ \\
\hline H3402 x Tomito & $89.00 \pm 7.34^{\mathrm{a}}$ & $65.25 \pm 17.46^{\mathrm{ab}}$ & $89.25 \pm 4.34 \mathrm{~ns}$ & $1.75 \pm 0.21 \mathrm{~ns}$ \\
\hline Pvalues & $<0.001$ & $<0.001$ & 0.15 & 0.436 \\
\hline F values & 5.08 & 5.23 & 1.68 & 1.03 \\
\hline
\end{tabular}

The data are reported as mean \pm standard deviation. a,beans followed by the different letters are statistically significant at $\mathrm{P}<0.05$; ns, not significant, Ch, index of chlorophyll content in the leaves; Flv, index of flavonoid content in the leaves; Antho, index of anthocyanin content in the leaves; NBI, nitrogen balance index. FM, 'H3402' grafted onto 'Tomito' and inoculated with Funneliformis mosseae, PG,'H3402' grafted onto 'Tomito' and inoculated with Paraburkholderia graminis C4D1M, AB,'H3402' grafted onto 'Tomito' and inoculated with Azospirillum brasiliensis sp 245, CM FM, 'H3402' grafted onto 'Tomito' and inoculated with F. mosseae, P. graminis C4D1M and A. brasiliensis sp 245, CM, 'H3402' grafted onto 'Tomito' and inoculated with P. graminis C4D1M and A. brasiliensis sp 245, 'H3402' = 'H3402' non-grafted and non-inoculated, H3402 x H3402 = 'H3402' selfgrafted and non-inoculated, H3402 x Tomito = 'H3402' grafted onto 'Tomito' and non-inoculated.

Table 7. Treatment effects on morphological destructive parameters in field experiment at fruit development.

\begin{tabular}{lccccc} 
Treatments & Leaf dry weight $(\mathrm{g})$ & Steam dry weight $(\mathrm{g})$ & Root dry weight $(\mathrm{g})$ & Fruit dry weight $(\mathrm{g})$ & Plant total dry weight $(\mathrm{g})$ \\
FM & $63.32 \pm 15.20^{\mathrm{ab}}$ & $31.70 \pm 5.29^{\mathrm{abc}}$ & $11.04 \pm 0.97^{\mathrm{b}}$ & $49.71 \pm 2.36^{\mathrm{abc}}$ & $155.8 \pm 17.31^{\mathrm{bcde}}$ \\
MICOSAT F & $73.36 \pm 18.93^{\mathrm{ab}}$ & $41.43 \pm 6.04^{\mathrm{ab}}$ & $16.18 \pm 2.69^{\mathrm{ab}}$ & $60.12 \pm 11.78^{\mathrm{abc}}$ & $191.1 \pm 30.92^{\mathrm{abc}}$ \\
\hline PG & $76.81 \pm 16.58^{\mathrm{ab}}$ & $36.97 \pm 6.39^{\mathrm{abc}}$ & $20.41 \pm 1.83^{\mathrm{a}}$ & $68.72 \pm 8.21^{\mathrm{a}}$ & $202.9 \pm 17.13^{\mathrm{ab}}$ \\
AB & $47.25 \pm 12.56^{\mathrm{b}}$ & $41.31 \pm 2.19^{\mathrm{ab}}$ & $14.55 \pm 3.61^{\mathrm{ab}}$ & $41.09 \pm 7.62^{\mathrm{bcd}}$ & $144.2 \pm 15.17^{\mathrm{cde}}$ \\
\hline CM FM & $98.4 \pm 14.44^{\mathrm{a}}$ & $44.03 \pm 5.00^{\mathrm{a}}$ & $17.39 \pm 3.74^{\mathrm{ab}}$ & $61.63 \pm 16.08^{\mathrm{ab}}$ & $221.5 \pm 37.23^{\mathrm{a}}$ \\
CM & $67.68 \pm 9.96^{\mathrm{ab}}$ & $30.86 \pm 4.87^{\mathrm{abc}}$ & $9.59 \pm 4.75^{\mathrm{b}}$ & $73.56 \pm 11.16^{\mathrm{a}}$ & $181.7 \pm 18.4^{\mathrm{abcd}}$ \\
\hline H3402 & $56.71 \pm 10.16^{\mathrm{b}}$ & $27.52 \pm 3.77^{\mathrm{bc}}$ & $13.30 \pm 3.09^{\mathrm{ab}}$ & $23.4 \pm 9.64^{\mathrm{d}}$ & $120.9 \pm 16.83^{\mathrm{e}}$ \\
H3402 x H3402 & $59.28 \pm 12.19^{\mathrm{b}}$ & $22.67 \pm 4.83^{\mathrm{c}}$ & $13.73 \pm 1.41^{\mathrm{ab}}$ & $36.21 \pm 5.12^{\mathrm{cd}}$ & $131.9 \pm 18.25^{\mathrm{de}}$ \\
\hline H3402 x Tomito & $73.68 \pm 12.77^{\mathrm{ab}}$ & $42.91 \pm 9.99^{\mathrm{a}}$ & $15.54 \pm 4.30^{\mathrm{ab}}$ & $52.44 \pm 9.97^{\mathrm{abc}}$ & $184.6 \pm 25.39^{\mathrm{abcd}}$ \\
P values & $<0.001$ & $<0.001$ & 0.002 & $<0.001$ & $<0.001$ \\
\hline F values & 4.43 & 7.03 & 4.19 & 10.83 & 8.74 \\
\hline
\end{tabular}

The data are reported as mean \pm standard deviation. a,b,c,de, Means followed by the different letters are statistically significant at $\mathrm{P}<0.05$; ns, not significant, Ch, index of chlorophyll content in the leaves; Flv, index of flavonoid content in the leaves; Antho, index of anthocyanin content in the leaves; NBI, nitrogen balance index. FM, 'H3402' grafted onto 'Tomito' and inoculated with Funneliformis mosseae, PG, 'H3402' grafted onto 'Tomito' and inoculated with Paraburkholderia graminis C4D1M, AB,'H3402' grafted onto 'Tomito' and inoculated with Azospirillum brasiliensis sp 245, CM FM, 'H3402' grafted onto 'Tomito' and inoculated with F. mosseae, P. graminis C4D1M and A. brasiliensis sp 245, CM, 'H3402' grafted onto 'Tomito' and inoculated with P. graminis C4D1M and A. brasiliensis sp 245, 'H3402' = 'H3402' non-grafted and non-inoculated, H3402 x H3402 = 'H3402' self-grafted and non-inoculated, H3402 x Tomito = 'H3402' grafted onto 'Tomito' and non-inoculated. 
sp.245 showed an increase in comparison with the non-grafted non-inoculated plants (Table 8). As far as fruit dry weight is considered (Table 9), we noticed that all the microbial biostimulants had a positive effect and the grafted plants inoculated with $A$. brasiliensis sp. 245 showed the highest values. On the contrary, there were no differences among the non-inoculated non-grafted, self-grafted and grafted onto 'Tomito' plants (Table 10). Grafted plants inoculated with bacterial consortium presented a striking effect on leaf dry weight. On the other hand, the main effects on stem dry weight were reported by $P$. graminis C4D1M inoculation, while the grafted plants inoculated with $F$. mosseae + all bacteria showed the highest root dry weights.

Concerning fruit quality (Table 10), grafting and microbial biostimulants improved the fruit quality. In particular, the grafted plants inoculated with $F$. mosseae produced tomatoes with the highest average fruit weight whereas inoculum with $A$. brasiliensis sp. 245 and the bacterial consortium increased the number of fruits. Interestingly, all the treatments reduced the incidence of the blossom-end rot physiological disorder, and the inoculation with $A$. brasiliensis sp. 245 increased the Brix $^{\circ}$ and Brix $\mathrm{t} \mathrm{ha}^{-1}$.

\section{Relationship between treatments and parameters assessed in open field}

The contributions of the two principal components were $33.06 \%$ (PC1) and 19.77\% (PC2) (Figure 3). PC2 separated the plants grafted onto 'Tomito' from non-grafted and self-grafted plants. P. graminis was associated with high values of several productive parameters (fruit dry weight, marketable yield and total yield). MICOSAT F UNO and microbial consortium (CM FM) were related to important parameters recorded at fruit development (stem, root and leaf dry weight, plant dry weight, number of leaves, etc). Whereas bacterial consortium (CM) was associated with physiological and morphological parameters (LAI, number of fruits and leaf dry weight) recorded at harvest time.

Table 8. Treatment effects on physiological parameters in field experiment at harvest time.

\begin{tabular}{|c|c|c|c|c|c|}
\hline Treatments & Chl & Flv & Antho & NBI & LAI \\
\hline $\mathrm{FM}$ & $28.96 \pm 3.5^{\mathrm{ab}}$ & $4.06 \pm 0.6^{\mathrm{bc}}$ & $0.63 \pm 0.01^{\mathrm{ab}}$ & $7.32 \pm 2.0^{\mathrm{a} a c}$ & $0.99 \pm 0.1 \mathrm{abcd}$ \\
\hline MICOSAT F & $34.10 \pm 2.9^{\mathrm{a}}$ & $4.57 \pm 0.2^{\mathrm{bc}}$ & $0.69 \pm 0.05^{\mathrm{ab}}$ & $7.50 \pm 1.1^{1 \mathrm{abc}}$ & $0.64 \pm 0.3^{\mathrm{d}}$ \\
\hline PG & $33.12 \pm 2.6^{\mathrm{a}}$ & $3.92 \pm 0.1^{\mathrm{c}}$ & $0.59 \pm 0.07^{\mathrm{b}}$ & $8.43 \pm 0.2^{\mathrm{a}}$ & $1.36 \pm 0.4^{\mathrm{ab}}$ \\
\hline $\mathrm{AB}$ & $22.03 \pm 1.6^{\mathrm{b}}$ & $6.01 \pm 0.1^{\mathrm{a}}$ & $0.64 \pm 0.05^{\mathrm{ab}}$ & $3.66 \pm 0.2^{\mathrm{c}}$ & $1.09 \pm 0.2^{\mathrm{abcd}}$ \\
\hline CM FM & $33.08 \pm 1.1^{\mathrm{a}}$ & $4.78 \pm 0.3^{\mathrm{abc}}$ & $0.56 \pm 0.01^{\mathrm{b}}$ & $6.95 \pm 0.7^{\mathrm{abc}}$ & $1.19 \pm 0.2^{\mathrm{abc}}$ \\
\hline $\mathrm{CM}$ & $33.72 \pm 3.4^{\mathrm{a}}$ & $4.42 \pm 0.2^{\mathrm{bc}}$ & $0.56 \pm 0.02^{\mathrm{b}}$ & $7.66 \pm 1.1^{\mathrm{ab}}$ & $1.49 \pm 0.5^{\mathrm{a}}$ \\
\hline H3402 & $21.81 \pm 3.7^{\mathrm{b}}$ & $5.43 \pm 0.6^{\mathrm{ab}}$ & $0.78 \pm 0.03^{\mathrm{a}}$ & $3.99 \pm 0.2^{\mathrm{bc}}$ & $0.91+0.1^{\mathrm{bcd}}$ \\
\hline H3402 x H3402 & $34.07 \pm 2.3^{\mathrm{a}}$ & $4.39 \pm 0.8^{b} \mathrm{c}$ & $0.56 \pm 0.04^{\mathrm{b}}$ & $8.05 \pm 2.2^{\mathrm{a}}$ & $1.09 \pm 0.1^{\mathrm{abcd}}$ \\
\hline H3402 x Tomito & $32.27 \pm 5.4^{\mathrm{a}}$ & $5.24 \pm 0.4^{\mathrm{abc}}$ & $0.77 \pm 0.08^{\mathrm{a}}$ & $6.22 \pm 1.4^{\mathrm{abc}}$ & $0.66 \pm 0.2^{\mathrm{cd}}$ \\
\hline Pvalues & $<0.001$ & $<0.001$ & $<0.001$ & $<0.001$ & $<0.001$ \\
\hline F values & 7.76 & 6.57 & 9.44 & 5.47 & 12.93 \\
\hline
\end{tabular}

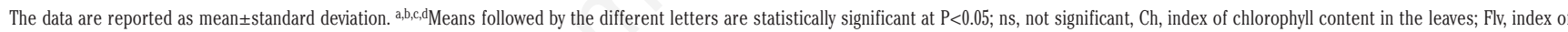
flavonoid content in the leaves; Antho, index of anthocyanin content in the leaves; NBI, nitrogen balance index. FM, 'H3402' grafted onto 'Tomito' and inoculated with Funneliformis mosseae, PG,'H3402' grafted onto 'Tomito' and inoculated with Paraburkholderia graminis C4D1M, AB,'H3402' grafted onto 'Tomito' and inoculated with Azospirillum brasiliensis sp 245, CM FM, 'H3402' grafted onto 'Tomito' and inoculated with F. mosseae, P. graminis C4D1M and A. brasiliensis sp 245, CM, 'H3402' grafted onto 'Tomito' and inoculated with P. graminis C4D1M and A. brasiliensis sp 245, 'H3402' = 'H3402' non-grafted and non-inoculated, H3402 x H3402 = 'H3402' self-grafted and non-inoculated, H3402 x Tomito = 'H3402' grafted onto 'Tomito' and non-inoculated.

Table 9. Treatment effects on morphological destructive parameters in field experiment at harvest time.

\begin{tabular}{|c|c|c|c|c|c|}
\hline Treatments & $\begin{array}{l}\text { Fruit dry weight } \\
\left.\qquad \text { (g plant }^{-1}\right)\end{array}$ & $\begin{array}{l}\text { Leaf dry weight } \\
\left.\text { (g plant }{ }^{-1}\right)\end{array}$ & $\begin{array}{l}\text { Strem dry weight } \\
\left(\text { g plant }^{-1}\right)\end{array}$ & $\begin{array}{l}\text { Root dry weight } \\
\left.\text { (g plant }{ }^{-1}\right)\end{array}$ & $\begin{array}{l}\text { Plant total dry weight } \\
\left.\text { (g plant }{ }^{-1}\right)\end{array}$ \\
\hline FM & $123.8 \pm 2.2^{\mathrm{bc}}$ & $52.64 \pm 0.4^{\mathrm{bc}}$ & $50.11 \pm 1.3^{b}$ & $11.33 \pm 1.9 \mathrm{e}$ & $237.80 \pm 2.6^{\mathrm{d}}$ \\
\hline MICOSAT F & $137.2 \pm 9.2^{\mathrm{ab}}$ & $40.08 \pm 4.4^{c}$ & $44.99 \pm 6.4^{b}$ & $24.18 \pm 1.4^{\mathrm{ab}}$ & $246.50 \pm 2.8^{\text {cd }}$ \\
\hline $\mathrm{PG}$ & $136.9 \pm 4.6^{\mathrm{ab}}$ & $70.65 \pm 8 . .^{\mathrm{ab}}$ & $78.47 \pm 6.7^{\mathrm{a}}$ & $18.2 \pm 2.4^{\text {abcde }}$ & $304.30 \pm 18.5^{\mathrm{a}}$ \\
\hline $\mathrm{AB}$ & $148.5 \pm 0.8^{a}$ & $60.58 \pm 1.1^{\mathrm{ab}}$ & $61.54 \pm 5.0^{\mathrm{ab}}$ & $12.45 \pm 0.5^{\mathrm{de}}$ & $283.05 \pm 6.5 \mathrm{abc}$ \\
\hline CM FM & $140.8 \pm 7.1^{\mathrm{ab}}$ & $63.55 \pm 3.5^{\mathrm{ab}}$ & $64.11 \pm 8.2^{\mathrm{ab}}$ & $26.69 \pm 6.5^{\mathrm{a}}$ & $295.16 \pm 4.7^{\mathrm{ab}}$ \\
\hline $\mathrm{CM}$ & $138.1 \pm 7.2^{\mathrm{ab}}$ & $76.92 \pm 10.7^{\mathrm{a}}$ & $68.02 \pm 4.7^{\mathrm{ab}}$ & $14.11 \pm 2.0^{\text {cde }}$ & $297.15 \pm 2.4^{\mathrm{a}}$ \\
\hline $\mathrm{H} 3402$ & $112.4 \pm 6.2^{\mathrm{c}}$ & $53.84 \pm 2.6^{\mathrm{bc}}$ & $50.86 \pm 10.3^{b}$ & $20.99 \pm 3.3^{\mathrm{abcd}}$ & $238.06 \pm 11.4^{\mathrm{d}}$ \\
\hline H3402 x H3402 & $111.5 \pm 11.6^{c}$ & $60.53 \pm 9.9 \mathrm{ab}$ & $57.05 \pm 11.1^{\mathrm{ab}}$ & $23.07 \pm 2.9 \mathrm{abc}$ & $252.20 \pm 33.4^{4 c d}$ \\
\hline H3402 x Tomito & $111.5 \pm 0.1^{\mathrm{c}}$ & $38.16 \pm 3.2^{c}$ & $61.94 \pm 11.4^{\mathrm{ab}}$ & $16.13 \pm 1.2^{\text {bcde }}$ & $227.70 \pm 9.6^{\mathrm{d}}$ \\
\hline Pvalues & $<0.001$ & $<0.001$ & 0.002 & $<0.001$ & $<0.001$ \\
\hline Fvalues & 14.27 & 11.74 & 5.03 & 9.99 & 12.75 \\
\hline
\end{tabular}

The data are reported as mean \pm standard deviation. a,b,c,de, Means followed by the different letters are statistically significant at $\mathrm{P}<0.05$; ns, not significant, Ch, index of chlorophyll content in the leaves; Flv, index of flavonoid content in the leaves; Antho, index of anthocyanin content in the leaves; NBI, nitrogen balance index. FM, 'H3402' grafted onto 'Tomito' and inoculated with Funneliformis mosseae, PG,'H3402' grafted onto 'Tomito' and inoculated with Paraburkholderia graminis C4D1M, AB,'H3402' grafted onto 'Tomito' and inoculated with Azospirillum brasiliensis sp 245, CM FM, 'H3402' grafted onto 'Tomito' and inoculated with $F$. mosseae, P. graminis C4D1M and A. brasiliensis sp 245, CM, 'H3402' grafted onto 'Tomito' and inoculated with P. graminis C4D1M and A. brasiliensis sp 245, 'H3402' = 'H3402' non-grafted and non-inoculated, H3402 x H3402 = 'H3402' self-grafted and non-inoculated, H3402 x Tomito = 'H3402' grafted onto 'Tomito' and non-inoculated. 


\section{Discussion}

\section{Greenhouse experiment}

Flowering is a crucial developmental stage for most herbaceous crops and the change of the flowering time could be an important strategy for either tailoring the crop life cycle, to fit different environments and to reduce the transition from vegetative to reproductive stage (Waseem et al., 2019). In fact, in Lycopersicon esculentum the use of microorganisms, capable of improving the root assimilation of soil nutrients, accelerated the vegetative phase by reducing the transition times with the reproductive phase (Di Martino et al 2019). Lu et al. (2018) reported that rhizosphere microorganisms can influence the timing of plant flowering, as also observed in our experiment where seedlings inoculated with A. brasiliensis showed an early flowering development (data not shown) and an increased number of flower production followed by bacterial consortium (CM).

The use of bacterial consortium (CM) improved the effect of the use of single species on some agronomic parameter such as leaf dray weight, stem dry weight, plant total dry weight as well as reported by previously works (Madhaiyan et al. 2010, Nain et al., 2010).

Yield

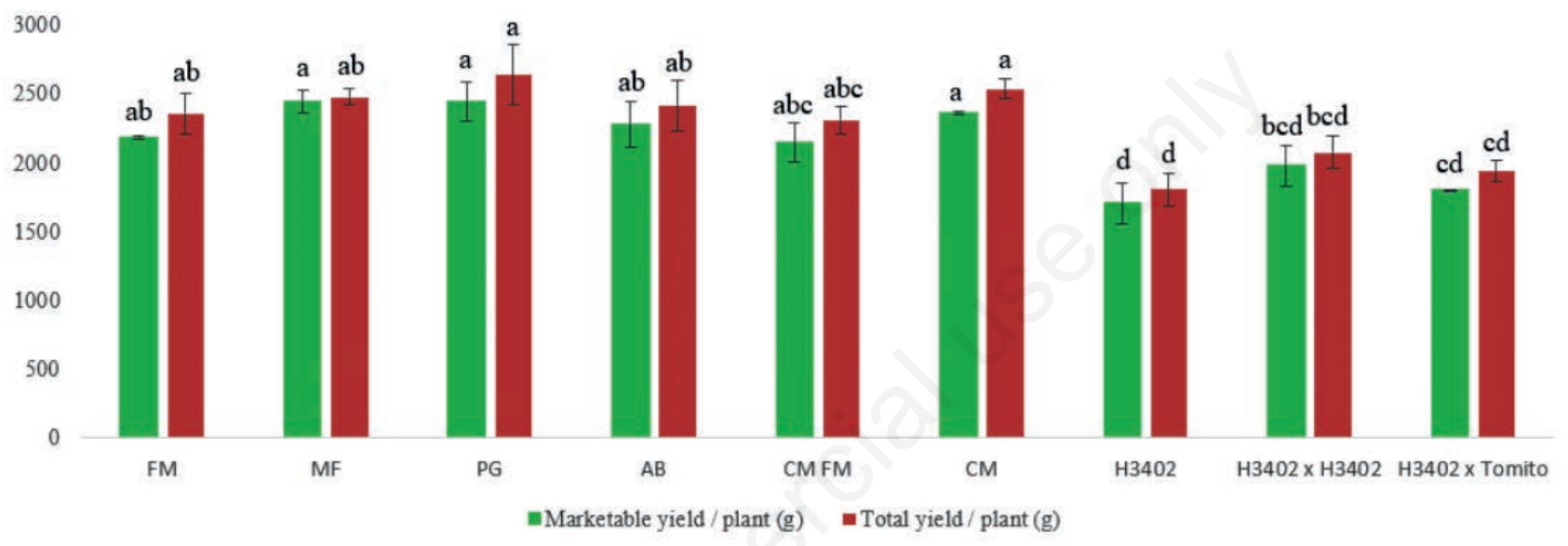

Figure 2. Mean values of marketable yield (green) and total yield (red) in processing tomato plants inoculated with different plant biostimulants and grafted on a cherry genotype. Vertical bars represent significant differences at $\mathrm{p}<0.05$. $\mathrm{FM}=$ ' $\mathrm{H} 3402$ ' grafted onto 'Tomito' and inoculated with Funneliformis mosseae, MF = 'H3402' grafted onto 'Tomito' and inoculated with Micosat F UNO; PG = 'H3402' grafted onto 'Tomito' and inoculated with Paraburkholderia graminis C4D1M, AB = 'H3402' grafted onto 'Tomito' and inoculated with Azospirillum brasiliensis sp 245, CM FM = 'H3402' grafted onto 'Tomito' and inoculated with $F$. mosseae, $P$. graminis $\mathrm{C} 4 \mathrm{D} 1 \mathrm{M}$ and $\mathrm{A}$. brasiliensis sp 245, CM = 'H3402' grafted onto 'Tomito' and inoculated with $P$. graminis $\mathrm{C} 4 \mathrm{D} 1 \mathrm{M}$ and $A$. brasiliensis sp 245, 'H3402' = 'H3402' non-grafted and non-inoculated, H3402 x H3402 = 'H3402' self-grafted and non-inoculated, H3402 x Tomito = 'H3402' grafted onto 'Tomito' and non-inoculated.

Table 10. Treatment effects on fruit quality parameters in field experiment at harvest time.

\begin{tabular}{|c|c|c|c|c|c|c|}
\hline Treatments & $\begin{array}{l}\text { Avarage fruit } \\
\text { weight }(\mathrm{g})\end{array}$ & $\begin{array}{c}\text { Number of fruits } \\
\left.\text { (piant }^{-1}\right)\end{array}$ & $\begin{array}{l}\text { BER fruits } \\
\left.\text { (no plant }{ }^{-1}\right)\end{array}$ & $\mathrm{pH}$ & BRIX $^{\circ}$ & BRIX $\mathrm{t} \mathrm{ha}^{-1}$ \\
\hline FFM & $68.66 \pm 0.5^{\mathrm{a}}$ & $34.35 \pm 2.3^{\mathrm{bc}}$ & $0.50 \pm 0.00^{\mathrm{b}}$ & $4.17 \pm 0.1 \mathrm{~ns}$ & $5.13 \pm 0.2^{b}$ & $2.80 \pm 0.10^{\mathrm{ab}}$ \\
\hline MICOSAT F & $62.46 \pm 1.8^{\mathrm{abcd}}$ & $39.67 \pm 2.1^{\mathrm{ab}}$ & $1.00 \pm 0.50^{\mathrm{b}}$ & $4.27 \pm 0.1 \mathrm{~ns}$ & $5.47 \pm 0.2^{2 \mathrm{~b}}$ & $3.33 \pm 0.04^{\mathrm{ab}}$ \\
\hline PG & $64.80 \pm 0.4^{\mathrm{ab}}$ & $40.70 \pm 3.1^{\mathrm{ab}}$ & $0.00 \pm 0.00^{\mathrm{b}}$ & $4.29 \pm 0.2 \mathrm{~ns}$ & $5.37 \pm 0.5^{\mathrm{ab}}$ & $3.29 \pm 0.52^{\mathrm{ab}}$ \\
\hline $\mathrm{AB}$ & $53.06 \pm 2.7^{\mathrm{e}}$ & $45.51 \pm 3.1^{\mathrm{a}}$ & $1.17 \pm 0.28^{b}$ & $4.15 \pm 0.0 \mathrm{~ns}$ & $6.23 \pm 0.1^{\mathrm{a}}$ & $3.54 \pm 0.23^{\mathrm{a}}$ \\
\hline CM FM & $63.60 \pm 0.6^{\mathrm{abc}}$ & $36.28 \pm 1.2^{\mathrm{bc}}$ & $2.83 \pm 0.28^{\mathrm{ab}}$ & $4.26 \pm 0.1 \mathrm{~ns}$ & $5.50 \pm 0.2^{\mathrm{ab}}$ & $2.95 \pm 0.30^{\mathrm{ab}}$ \\
\hline $\mathrm{CM}$ & $56.54 \pm 3.1^{\mathrm{de}}$ & $44.92 \pm 1.1^{\mathrm{a}}$ & $2.33 \pm 0.76^{\mathrm{ab}}$ & $4.37 \pm 0.1 \mathrm{~ns}$ & $5.20 \pm 0.5^{b}$ & $3.07 \pm 0.30^{\mathrm{ab}}$ \\
\hline H3402 & $56.40 \pm 3.6^{\text {de }}$ & $31.98 \pm 0.1^{\mathrm{c}}$ & $5.83 \pm 2.25^{\mathrm{a}}$ & $4.29 \pm 0.0 \mathrm{~ns}$ & $5.90 \pm 0.2^{2 \mathrm{~b}}$ & $2.50 \pm 0.13^{b}$ \\
\hline H3402 x H3402 & $57.94 \pm 2.9$ cde & $35.92 \pm 3.8^{\mathrm{bc}}$ & $5.50 \pm 3.00^{\mathrm{a}}$ & $4.31 \pm 0.0 \mathrm{~ns}$ & $5.87 \pm 0.2^{\mathrm{ab}}$ & $2.91 \pm 0.34^{\mathrm{ab}}$ \\
\hline H3402 x Tomito & $60.80 \pm 0.4^{\mathrm{bcd}}$ & $31.85 \pm 1.4^{c}$ & $2.33 \pm 0.28^{\mathrm{ab}}$ & $4.23 \pm 0.1 \mathrm{~ns}$ & $6.00 \pm 0.2^{2 \mathrm{~b}}$ & $2.69 \pm 0.07^{\mathrm{b}}$ \\
\hline Pvalues & $<0.001$ & $<0.001$ & $<0.001$ & 0.19 & 0.004 & 0.004 \\
\hline$\underline{F}$ values & 15.35 & 14.29 & 7.30 & 1.61 & 4.47 & 4.48 \\
\hline
\end{tabular}

The data are reported as mean \pm standard deviation. a,bMeans followed by the different letters are statistically significant at $\mathrm{P}<0.05$; ns, not significant, Ch, index of chlorophyll content in the leaves; Flv, index of flavonoid content in the leaves; Antho, index of anthocyanin content in the leaves; NBI, nitrogen balance index. FM, 'H3402' grafted onto 'Tomito' and inoculated with Funneliformis mosseae, PG,' $\mathrm{H} 3402$ ' grafted onto 'Tomito' and inoculated with Paraburkholderia graminis C4D1M, AB,'H3402' grafted onto 'Tomito' and inoculated with Azospirillum brasiliensis sp 245, CM FM, 'H3402' grafted onto 'Tomito' and inoculated with $F$ mosseae, P. graminis C4D1M and A. brasiliensis sp 245, CM, 'H3402' grafted onto 'Tomito' and inoculated with P. graminis C4D1M and A. brasiliensis sp 245, 'H3402' = 'H3402' non-grafted and non-inoculated, H3402 $\mathrm{x}$ H3402 = 'H3402' self-grafted and non-inoculated, H3402 x Tomito = 'H3402' grafted onto 'Tomito' and non-inoculated. 


\section{Field experiment}

The combined use of grafting and microbial biostimulants increased marketable and total yields of the commercial processing tomato genotype 'H3402'. However, the contribution of the rootstock on the increment of the marketable yield was lower than expected. These results were due to the high incidence of light blight occurred in open field. In fact, the oomicetes P. infestans may lead a decrease of yield tomato (Fontem et al. 1999). Therefore, new studies could be carried out to assess the performances of the rootstock investigated in the present study and its interactions with the inoculated microorganisms in different environmental conditions. The plants grafted onto 'Tomito' and inoculated with P. graminis $\mathrm{C} 4 \mathrm{D} 1 \mathrm{M}$, Micosat F UNO and the bacterial consortium achieved the highest marketable yield. The increase of marketable yield was linked both to the increment of number of fruits and to an increase of the average fruit weight. In particular, P. graminis $\mathrm{C} 4 \mathrm{D} 1 \mathrm{M}$ influenced both the number and the weight of the fruits; Micosat F UNO influenced mainly the fruit number, while the effect of bacteria consortium was intermediate between P. graminis and A. brasiliensis. The treatment based on bacteria consortium positively influenced the majority of parameters assessed in open field at both fruit development and harvest time. Number of flowers was not recorded in open field but bacteria consortium recorded the highest value of number of fruit, suggesting that this treatment putatively also produced the highest number of flowers as highlighted in the experiment performed in greenhouse. These results are partially in agreement with Candido et al. (2013) that found an increase of number and weight of fruits in the cherry tomato genotype 'HF1 PX 02325715' inoculated with Micosat F UNO.

In leaf, chlorophyll is a key pigment in the photosynthesis activity as it is responsible for absorbing light energy (Di Martino et al., 2019). Our results showed that all the treatments significantly increased the content of chlorophyll in the greenhouse experiment, while in field experiment the positive effect of rootstock was not observed. The increased chlorophyll content in response to treatment is correlated to the improvement of uptake of nutrient from soil and in particular of nitrogen, the main component influencing this pigment. In addition, a recent study showed that $P$. graminis can produce gramibactin, an siderophore that can bind iron, an essential element for chlorophyll production (Hermenau et al., 2018).

Leaf area index (LAI) is an important parameter used for monitoring the crop growth as it indicates the capacity of plant canopies to exchange energy and organic matter with environment (Niinemets and Tobias, 2019). In the present study, plants inoculated with P. graminis C4D1M showed a significant increment of LAI that should be ascribed to a plant growth promoting effect of rhizobacterium. Our results showed that the inoculation of processing tomato with plant biostimulants significantly increased vegetative growth (plant height, number of leaves, plant dry weight and

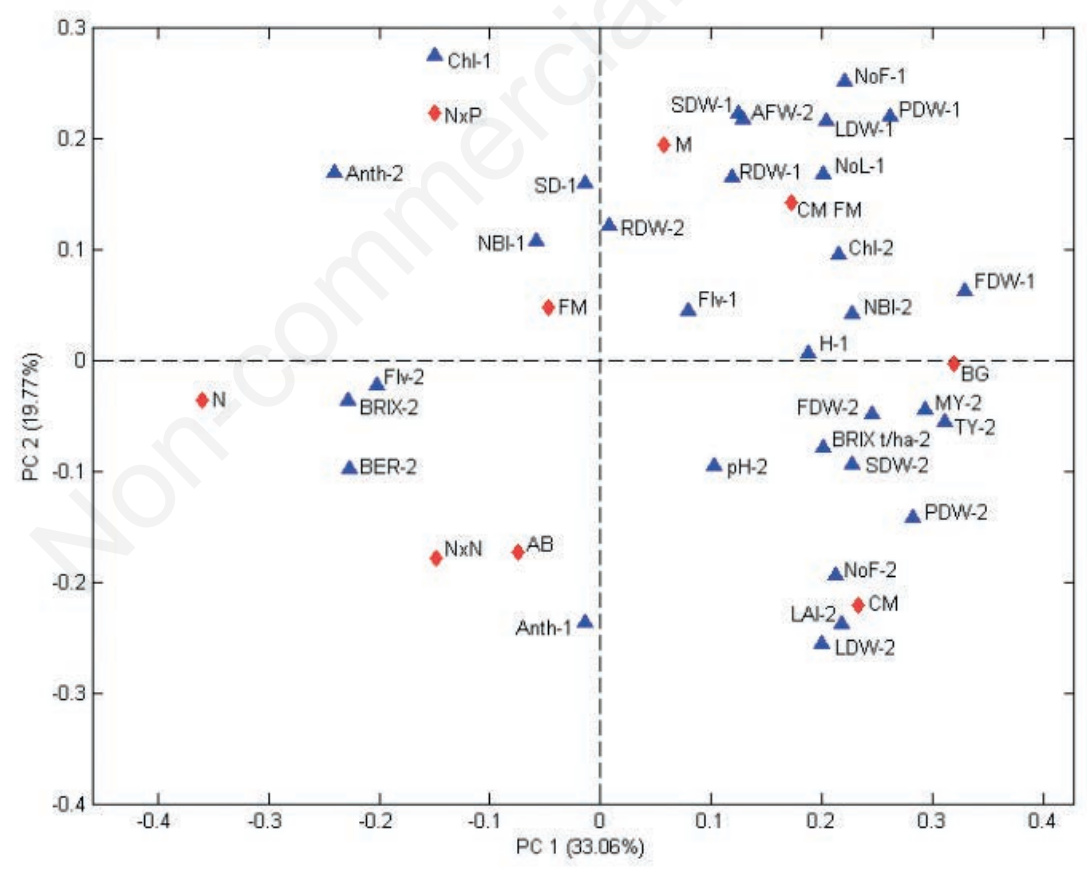

Figure 3. Biplot of PCA for the field experiment. 1 = parameters assessed at fruit development, 2 = parameters assessed at harvest time, $\mathrm{Chl}=$ index of chlorophyll content in the leaves; Flv = index of flavonoid content in the leaves; Anth = index of anthocyanin content in the leaves; $\mathrm{NBI}=$ nitrogen balance index, $\mathrm{H}=$ plant height, $\mathrm{SD}=$ stem diameter, $\mathrm{NoL}=$ number of leaves, NoF = number of fruits, $\mathrm{H} / \mathrm{D}=$ ratio between plant height and stem diameter, $\mathrm{LDW}=$ Leaf dry weight, SDW = stem dry weight, RDW = root dry weight, FDR = fruit dry weight, $\mathrm{PDW}=$ plant dry weight, $\mathrm{LAI}=$ leaf area index, AFW = average fruit weight, MY $=$ marketable yield, TY = total yield, $M=$ H3402' grafted onto 'Tomito' and inoculated with MICOSAT F UNO, FM = 'H3402' grafted onto 'Tomito' and inoculated with Funneliformis mosseae, PG = 'H3402' grafted onto 'Tomito' and inoculated with Paraburkholderia graminis $\mathrm{C} 4 \mathrm{D} 1 \mathrm{M}, \mathrm{AB}=$ 'H3402' grafted onto 'Tomito' and inoculated with Azospirillum brasiliensis sp 245, CM FM = 'H3402' grafted onto 'Tomito' and inoculated with $F$. mosseae, P. graminis C4D1M and A. brasiliensis sp 245, CM = 'H3402' grafted onto 'Tomito' and inoculated with P. graminis C4D1M and $A$. brasiliensis sp $245, \mathrm{~N}=$ ' $\mathrm{H} 3402$ ' non-grafted and non-inoculated, $\mathrm{NxN}=$ ' $\mathrm{H} 3402$ ' self-grafted and noninoculated, $\mathrm{NxP}=$ ' $\mathrm{H} 3402$ ' grafted onto 'Tomito' and non-inoculated. 
single organ dry weight) of the processing tomato plants. However, the distribution of the dry matter in the organ depend on treatments. Similar effects of plant biostimulants on crop growth were reported also in other studies (Roesti et al., 2006; Rahman et al., 2018). Rahman et al., 2018 reported that the increase of shoot fresh weight is higher in the strawberry inoculated with of Paraburkholderia fungorum rather than with Bacillus amyloliquefaciens. A recent study found that growth-promoting bacteria and arbuscular mycorrhizal fungi differentially benefit tomato and corn and these differences depended upon the supplied form of phosphorus (Saia et al., 2019).

Blossom-end rot (BER) is a physiological disorder that causes important economic losses (Hagassou et al., 2019). Although BER is linked to the concentration of calcium available in the soil solution, other factors are also involved in its occurrence such as reduced nutrient and water uptake and the rapid cell expansion in the distal fruit tissue (Ho and White, 2005; de Freitas and Mitcham, 2012). Moreover, a lower incidence of BER in some varieties like cherry, cocktail, or round tomato types was reported (Grasselly et al., 2008; Boari et al., 2016), indicating that fruit shape influences BER occurrence. Although a reduced number of fruits affected by BER was observed for all treatments, in the present study the lower incidence of BER might not depend on fruit shape but on other factors such as the use of the cherry rootstock genotype and the interactions among rootstock, scion and plant biostimulant inoculations.

The solid soluble content $\left({ }^{\circ} \mathrm{Brix}\right)$ is an important parameter of commercial quality of tomato juice. In addition, the Brix yield (Brix $\mathrm{t} \mathrm{ha}^{-1}$ ) is a parameter that puts in correlation the harvest and marketable yield with the main quality parameter ( ${ }^{\circ}$ Brix), therefore it is very important in determining the farm income. In the present study, $A$. brasiliensis sp. 245 increased the quality of fruit reaching the highest ${ }^{\circ}$ Brix and Brix yield. Our results are in accordance with Ordookhani and Zare (2011), who found similar increase of soluble solid content using PGPR (Pseudomonas putida, Azotobacter chroococcum) and AMF (F. mosseae).

The use of microbial biostimulants could be a sustainable strategy to reduce the current yield gap between OFS and CFS. Microorganism inoculation (timing and number of applications) and formulation (concentration, co-formulants, adjuvants and consortium of the microorganisms) should be improved to make more effective the treatment also in open field, where environmental factors and microorganisms already present in the rhizosphere might influence the activity of the inoculated microorganisms.

\section{Conclusions}

Our results confirm the positive role of grafting in the improvement of agronomic and fruit quality parameters. The proposed cherry ('Tomito') rootstock positively influenced morphological and physiological parameters of processing tomato when cultivated in greenhouse, while these effects were reduced by environmental factors when cultivated in open field. Among the investigated microbial biostimulants, $P$. graminis C4D1M, A. breailiensis sp. 245 and bacterial consortium positively affected processing tomato growth, fruit yield and quality in sustainable farming systems. A. brasiliensis sp. 245 might be used to induce an early flowering and higher flower production, reducing the growing season and increasing the productivity of processing tomato. Further studies should be carried out to confirm our results, by modifying the number of treatments, the timing of inoculation, inoculum concen- tration or testing some adjuvant in order to improve the treatment in open field.

\section{References}

Bettiol W, Ghini R, Galvão JAH, Siloto RC, 2004. Organic and conventional tomato cropping systems. Sci. Agric. 61:253-9.

Boari F, Donadio A, Pace B, Schiattone MI, Cantore V, 2016. Kaolin improves salinity tolerance, water use efficiency and quality of tomato. Agric. Water Manag. 167:29-37.

Candido V, Campanelli G, D’Addabbo T, Castronuovo D, Renco M, Camele I, 2013. Growth and yield promoting effect of articificial mycorrhization combined with different fertiliser rates on field-grown tomato. Ital. J. Agron. 8:168-74.

Caradonia F, Francia E, Morcia C, Ghizzoni R, Moulin L, Terzi V, and Ronga D, 2019. Arbuscular Mycorrhizal Fungi and Plant Growth Promoting Rhizobacteria Avoid Processing Tomato Leaf Damage during Chilling Stress. Agronomy 9:299.

da Silva EC, Muraoka T, Bastos AVS, Franzin VI, Buzetti S, Soares FAL, Teixeira MA, Bendassolli JA, 2020. Biomass and nutrient accumulation by cover crops and upland rice grown in succession under no-tillage system as affected by nitrogen fertilizer rate. J. Crop Sci. Biotechnol. 23:117-26.

Di Martino C, Fioretto A, Palmieri D, Torino V, Palumbo G, 2019. Influence of Tomato Plant Mycorrhization on Nitrogen Metabolism, Growth and Fructification on P-Limited Soil. J Plant Growth Regul. [Epub ahead of print].

Djidonou D, Zhao X, Simonne EH, Koch KE, Erickson JE, 2013. Yield, water, and nitrogen use efficiency in field grown, grafted tomatoes. Hortsci. 48:485-92.

Drobek M, Frąc M, Cybulska J, 2019. Plant Biostimulants: Importance of the Quality and Yield of Horticultural Crops and the Improvement of Plant Tolerance to Abiotic Stress - A Review. Agronomy 9:335.

Dumas Y, Dadomo M, Di Lucca G, and Grolier P, 2003. Effects of environmental factors and agricultural techniques on antioxidant content of tomatoes. J. Sci. Food Agric. 83:369-82.

El-Esawi MA, Al-Ghamdi AA, Ali HM, Alayafi AA, 2019. Azospirillum lipoferum FK1 confers improved salt tolerance in chickpea (Cicer arietinum L.) by modulating osmolytes, antioxidant machinery and stress-related genes expression. Environ. Exp. Bot. 159:55-65.

European Parliament and Council of the European Union, 2019. Regulation (EU) 2019/1009 of the European Parliament and of the Council of 5 June 2019 laying down rules on the making available on the market of EU fertilising products and amending Regulations (EC) No 1069/2009 and (EC) No 1107/2009 and repealing Regulation (EC) No 2003/2003. Official Journal of the European Union, L 170/1.

FAO, 2019. Available from: http://www.fao.org/faostat/ en/\#data/QC

Farneselli M, Benincasa P, Tosti G, Pace R, Tei F, Guiducci M, 2013. Nine-year results on maize and processing tomato cultivation in an organic and in a conventional low input cropping system. Ital. J. Agron 8:9-13.

Ferrol N, Azcòon-Aguilar C, Pòerez-Tienda J, 2019. Review: Arbuscular mycorrhizas as key players in sustainable plant phosphorus acquisition: an overview on the mechanisms involved. Plant Sci. 280:441-7.

Flores FB, Sanchez-Bel P, Estañ MT, Martinez-Rodriguez MM, Moyano E, Morales B, Campos JF, Garcia-Abellán JO, Egea 
MI, Fernández-Garcia N, Romojaro F, CBolarín MC, 2010. The effectiveness of grafting to improve tomato fruit quality. Sci. Hortic. 125:211-7.

Fontem DA, Nono-Womdim R, Opena RT, Gumedzoe MYD, 1996. Impact of early and late blight infections on tomato yield. Trop. Vegetable Infor. Ser. 1:7-8.

Gouda S, Kerry RG, Das G, Paramithiotis S, Shin HS, Patra JK, 2018. Revitalization of plant growth promoting rhizobacteria for sustainable development in agriculture. Microbiol. Res. 206:131-40.

Grasselly D, Rosso L, Holgard S, Cottet V, Navez B, Jost M, Berier A, 2008. Soilless culture of tomato: effect of salinity of the nutrient solution. Infos. Ctifl. 239:41-5.

Kimura S, and Sinha N, 2008. Tomato (Solanum lycopersicum): A Model Fruit-Bearing Crop. Cold Spring Harb. Protoc. 3:11.

Hagassou D, Francia E, Ronga D, Buti M, 2019. Blossom end-rot in tomato (Solanum lycopersicum L.): A multi-disciplinary overview of inducing factors and control strategies. Sci. Hortic. 249:49-58.

Hermenau R, Ishida K, Gama S, Hoffmann B, Pfeifer-Leeg, M, Plass W, Mohr JF, Wichard T, Saluz HP, Hertweck C, 2018. Gramibactin - a bacterial siderophore with a diazeniumdiolate ligand system. Nat. Chem. Biol. 14:841-3.

ISI Sementi, 2020. Available from: www.isisementi.com/it/ Prodotti/Pomodoro-Cherry-a-pianta-determinata/283/TOMITO-F1/

Leogrande R, Lopedota O, Montemurro F, Vitti C, Ventrella D, 2012. Effects of irrigation regime and salinity on soil characteristics and yield of tomato. Ital. J. Agron. 7:50-7.

Lu T, Ke MJ, Lavoie M, Jin YJ, Fan XJ, Zhang ZY, Fu ZW, Sun LW, Gillings M, Penuelas J, 2018. Rhizosphere microorganisms can influence the timing of plant flowering. Microbiome 6:e231.

Madhaiyan, M, Poonguzhali, S, Kang B, Lee Y-G, Chung J-B \& Sa T-M, 2010. Effect of co-inoculation of methylotrophic Methylobacterium oryzae with Azospirillum brasilense and Burkholderia pyrrocinia on the growth and nutrient uptake of tomato, red pepper and rice. Plant Soil 328:71-82.

Montano FP, Villegas CA, Bellogia RA, Cerro PD, Espuny MR, Guerrero IJ, López-Baena FJ, Ollero FJ,.Cubo T, 2014. Plant growth promotation in cereals and leguminous agricultural important plants from microorganisms capacities to crop production. Microbiol. Res. 169:325-36.

Mura S, Seddaiu G, Bacchini F, Roggero PP, Greppi G, 2013. Advances of nanotechnology in agro-environmental studies. Ital. J. Agron. 8:127-40.

Nain L, Rana A, Joshi M, Jadhav SD, Kumar D, Shivay YS, Paul S \& Prasanna R, 2010. Evaluation of synergistic effects of bacterial and cyanobacterial strains as biofertilizers for wheat. Plant Soil 331:217-30.

Niinemets Ü, Tobias M, 2019. Canopy leaf area index at its higher end: dissection of structural controls from leaf to canopy scales in bryophytes. N. Phytol. 223:118-33.

Pretty J, 2008. Agricultural sustainability: concepts, principles and evidence. Philos. Trans. R. Soc. Lond. B Biol. Sci. 363:447-65.

Raiola A, Rigano MM, Calafiore R, Frusciante L, Barone A, 2014. Enhancing the health-promoting effects of tomato fruit for biofor- tified food. Mediators Inflamm. pp. 1-16.

Rahman M, Sabir AA, Mukta JA, Khan MMA, Mohi-Ud-Din M, Miah MG, Islam MT, 2018. Plant probiotic bacteria Bacillus and Paraburkholderia improve growth, yield and content of antioxidants in strawberry fruit. Sci. Rep. 8:2504.

Roesti D, Gaur R, Johri BN, Imfeld G, Sharma S, Kawaljeet K, Aragno M, 2006. Plant growthstage, fertiliser management and bio-inoculation of arbuscular mycorrhizalfungi and plant growth promoting rhizobacteria affect the rhizobacterial community structure in rain-fed wheat fields. Soil Biol. Biochem. 38:1111-20.

Ronga D, Caradonia F, Francia E, Morcia C, Rizza F, Badeck F-W, Ghizzoni R, Terzi V, 2019b. Interaction of tomato genotypes and arbuscular mycorrhizal fungi under reduced irrigation. Horticulturae 5:79.

Ronga D, Caradonia F, Setti L, Hagassou D, Giaretta Azevedo CV, Milc J, Pedrazzi S, Allesina G, Arru L, Francia E, 2019c. Effects of innovative biofertilisers on yield of processing tomato cultivated in organic cropping systems in northern Italy. Acta Hortic. 1233:129-36.

Ronga D, Caradonia F, Parisi M, Bezzi G, Parisi B, Allesina G, Pedrazzi S, Francia E, 2020. Using digestate and biochar as fertilizers to improve processing tomato production sustainability. Agronomy 10:138.

Ronga D, Francia E, Rizza F, Badeck FW, Caradonia F, Montevecchi G, Pecchioni N, 2019d. Changes in yield components, morphological, physiological and fruit quality traits in processing tomato cultivated in Italy since the 1930's. Scientia Horticulturae 257:108726.

Ronga D, Gallingani T, Zaccardelli M, Perrone D, Francia E, Milc J, Pecchioni N, 2019a. Carbon footprint and energetic analysis of tomato production in the organic vs the conventional cropping systems in Southern Italy. J. Clean. 220:836-45.

Ronga D, Lovelli S, Zaccardelli M, Perronec D, Ulricia A, Francia E, Milc J, Pecchioni N, 2015. Physiological responses of processing tomato in organic and conventional Mediterranean cropping systems. Sci. Hortic. 190:161-72.

Ronga D, Zaccardelli M, Lovelli S, Perrone D, Francia E, Milc J, Ulrici A, Pecchioni N, 2017. Biomass production and dry matter partitioning of processing tomato under organic vs conventional cropping systems in a Mediterranean environment. Sci. Hortic. 224:163-70.

Saia S, Aissa E, Luziatelli F, Ruzzi M, Colla G, Ficca AG, Cardarelli M, Rouphael Y, 2019. Growth-promoting bacteria and arbuscular mycorrhizal fungi differentially benefit tomato and corn depending upon the supplied form of phosphorus. Mycorrhiza. 30:133-47.

Shameer S, Prasad T, 2018. Plant growth promoting rhizobacteria for sustainable agricultural practices with special reference to biotic and abiotic stresses. Plant Growth Regul. 84:603-15.

Zeffa DM, Perini LJ, Silva MB, de Sousa NV, Scapim CA, de Oliveira ALM, do Amaral Jùnior AT, Gonçalves LSA, 2019. Azospirillum brasilense promotes increases in growth and nitrogen use efficiency of maize genotypes. PLoS One 14:e0215332. 